\title{
Analysis of the microbial contamination levels in dried red pepper during production
}

\author{
Nguyen Bao Hung, Bohyun Yun, Won-Il Kim, Gyusuck Jung, Theresa Lee, \\ Eunjung Roh, Hyun Ju Kim, Seungdon Lee, Se-Ri Kim* \\ Microbial Safety Team, Agro-Food Safety and Crop Protection Department, National Institute of Agricultural Sciences (NAS), \\ Rural Development Administration (RDA), Wanju 5536, Korea
}

\section{건고추 생산 농장의 위생지표세균과 병원성미생물 오염도 조사}

\author{
웅웬바오훙·윤보현 · 김원일 · 정규석 · 이데레사 · 노은정 · 김현주 · 이승돈 · 김세리* \\ 농촌진흥청 국립농업과학원 농산물안전성부 유해생물팀
}

\begin{abstract}
The purpose of this study was to investigate the main source of contamination of dried red pepper by assessing microbial loads on red peppers, washing water, washing machines, harvesting containers, and worker gloves that had come in contact with the dried red pepper. To estimate microbial loads, indicator bacteria (total bacteria, coliform bacteria and Escherichia coli) and pathogenic bacteria (E. coli 0157:H7, Salmonella spp., Listeria monocytogenes, and Clostridium perfringens) were enumerated. The results showed that the numbers of indicator bacteria increased significantly after washing red peppers compared with that before washing $(\mathbf{p}<0.05)$. Moreover, $E$. coli and Listeria spp. were recovered from the red peppers after washing and from the ground water used in the washing process. The number of indicator bacteria on red peppers dried in the green house was lower than that on red peppers dried in a dry oven (p<0.05). However, E. coli O157:H7, Salmonella spp., L. monocytogenes, and C. perfringens were not detected. These results suggested that a disinfection technique may be needed during the washing step in order to prevent potential contamination. In addition, hygienic practices during the drying step using the dry oven, such as establishment of an optimal temperature, should be developed to enhance the safety of dried red pepper.
\end{abstract}

Key words : dried red pepper, indicator bacteria, food borne pathogens

\section{서 론}

고추(capsicum Annum L.)는 전 세계적으로 재배되며 주 로 풋고추, 홍고추, 건고추, 고춧가루 등의 형태로 소비되고 대부분이 고춧가루로 사용되고 있다 $(1,2)$.

미생물에 오염된 고춧가루를 식품가공의 부원료로 사용 하면 최종제품의 미생물학적 안전성에 영향을 줄 수 있다.

*Corresponding author. E-mail : seri81@korea.kr Phone : 82-63-238-3395, Fax : 82-63-238-3840

Received 9 January 2018; Revised 12 April 2018; Accepted 20 April 2018.

Copyright (c) The Korean Society of Food Preservation. All rights reserved.
고춧가루는 한국에서는 주로 고추장이나 김치, 젓갈류뿐만 아니라 조미료로 광범위하게 이용되고 있기 때문에 국민건 강을 위하여 고춧가루의 미생물 안전성 확보가 중요하다. 이에 식품의약품안전처에서는 고춧가루의 미생물 기준을 하워드 계수장치에 의한 곰팡이 양성비율을 $20 \%$ 이하, Escherichia coli는 $\mathrm{n}=5, \mathrm{c}=2, \mathrm{~m}=0, \mathrm{M}=10$, Clostridium perfringens는 g 당 100 이하로 규정하고 있다(3). 뿐만 아니 라 일본, 미국 등 수출상대국의 바이어들은 일반세균수 $\mathrm{g}$ 당 1,000 이하를 요구하고 있는 실정이다. 하지만 국내 유통 중인 고춧가루를 대상으로 미생물 분석한 결과에 따르면 일반세균수 $2.25 \times 10^{3}-1.84 \times 10^{6} \mathrm{CFU} / \mathrm{g}$, 대장균군의 경우 0$8.20 \times 10^{3} \mathrm{CFU} / \mathrm{g}$, 곰팡이의 경 우 $4.95 \times 10^{2}-3.19 \times 10^{6} \mathrm{CFU} / \mathrm{g}$ 수준으로 오염되어 있어 수출대상국 바이어들이 요구하는 
수준을 초과하고 있었다(4). 또한 Song 등(5)의 연구에서는 50 개의 시판 중인 고춧가루를 대상으로 대장균을 조사한 결과 하나의 시료에서 병원성 대장균이 검출되었다고 보고 되고 있어 고춧가루의 안전관리가 필요한 실정이다.

고춧가루나 향신료 중 미생물을 제어하고 안전성을 높이 기 위한 노력의 일환으로 세계 각국에서는 steam, 건조, microwave, 훈증처리, LED 처리, 방사선 처리, UV 처리 등 다양한 방법이 연구되고 현장에 적용되어 왔다(6-11). 이중 가장 오랜 기간 사용되어온 ethylene oxide 훈증법은 효과적으로 미생물을 저감하지만 안전성 문제로 국내외적 으로 사용이 금지되었으며(11,12), UV 처리의 경우 고춧가 루 생산 라인에 설치되어 이용되고 있으나, UV특성상 조사 거리에 영향을 많이 받기 때문에 생산 중에 미생물의 성장 을 효과적으로 저감하지 못한다고 보고되고 있다 $(13,14)$. 다른 대안으로 $2-7 \mathrm{kGy}$ 방사선을 처리하여 미생물을 효율 적으로 저감하는 방법들이 연구되었으나, 대중들이 방사선 조사를 꺼려하기 때문에 대중화가 어려운 문제가 있다(15).

이상의 결과들을 종합해 볼 때 고춧가루의 안전성은 고 춧가루를 제조하는 단계에서 제어한다는 것은 매우 어렵다 고 판단되며 원료인 건고추에서부터 식중독세균의 오염을 예방하는 것이 필요하다고 사료된다. 건고추를 생산하는 과정은 수확, 세척, 건조과정으로 이루어지는데 이 과정에 세척수, 작업자 손, 작업도구, 건조 환경 등에 의해 건고추가 미생물에 오염 될 가능성이 높다. 하지만 건고추 생산현장 에서는 미생물 관리에 대한 인식이 낮고 미생물 오염예방에 대한 실천 기술 개발이 전무한 실정이다.

따라서 본 연구는 고추 수확에서부터 건고추를 생산하는 과정까지 농가에서 실천할 수 있는 위생관리 가이드를 마련 하기 위한 기초 연구로 건고추를 생산하는 농가에서 생산단 계별 고추와 건고추 생산과정에 직접 접촉하는 시료를 수집 하여 위생지표세균과 병원성미생물을 조사하고 그 결과를 보고하고자 한다.

\section{재료 및 방법}

\section{시료 채취 및 전처리}

본 연구는 2017년 9월 시설 재배와 노지 재배 두가지 방법으로 건고추 생산농가 세 곳을 대상으로 수확, 세척, 건조 과정으로부터 시료를 채취하여 위생지표세균(일반세 균, 대장균군, E. coli)과 식중독세균(E. coli $\mathrm{O} 157: \mathrm{H7}$, Salmonella spp., Listeria monocytogenes, Clostridium perfringens)을 분석하였다. 건고추는 고추를 수확하고 세척 한 후에 비닐하우스 혹은 건조기를 이용하여 건조하는 방식 으로 생산된다. 비닐하우스에서 건조하는 방식은 세척한 고추를 차광막을 친 비닐하우스 내에 고추를 널고 하우스 문을 열어 3 일 정도 숙성시키고 이후 맛과 색을 좋게 하기
위하여 하우스의 문을 닫고 1 일간 건조하는데 이 과정에서 하우스 온도는 $75^{\circ} \mathrm{C}$ 까지 올라간다. 이 후 하우스 문을 개방 하여 6일간 더 건조하여 생산한다. 건조기를 사용하여 건조 하는 방식은 세척한 고추를 $55-60^{\circ} \mathrm{C}$ 로 설정된 농산물 건조 기에 넣고 3 일간 건조하는 방식이다.

본 연구에 사용된 고추는 수확 후, 세척 후, 비닐하우스에 서 4일 건조 후, 10 일 건조 후, 건조기(Sin-3000, Sinil, Daegu, Korea)에서 3일간 건조한 고추였다. 또한 각 단계별 고추와 생산과정 중 직접 접촉이 가능한 세척용수, 세척기 (Sin-3000, Sinil, Daegu, Korea), 수확용기, 작업자 장갑, 건 조기 표면 등 총 198 점을 채취하여 미생물 분석에 사용하였 다.

건고추 세척에 사용되는 용수는 지하수였으며 세척, 헹 굼 단계에서 각각 $2 \mathrm{~L}$ 를 채수병에 채취하였다. 작업자의 장갑은 건고추 세척과정에 종사하는 작업자를 대상으로 채취하였으며 glove juice법으로 채취하였다(16). Glove juice법은 멸균된 팩에 멸균된 생리식염수 $50 \mathrm{~mL}$ 을 붓고 장갑을 넣고 30초간 문지르는 방법이다. 또한 건고추의 생 산과정에서 세척기, 수확용기, 자연건조를 위해 건조장으 로 활용되는 비닐하우스 바닥 및 건조기 내부의 채반 등 평 판시료는 $10 \mathrm{~cm} \times 10 \mathrm{~cm}$ 크기의 면적대를 사용하여 100 $\mathrm{cm}^{2}$ 의 면적을 면봉으로 문질러 채취하였다. 채취된 시료는 아이스박스에 담아 실험실까지 운반한 후 24 시간 내에 분 석하였다.

\section{위생지표세균의 측정}

위생지표세균의 분석을 위하여 고추 및 건고추는 각각 $25 \mathrm{~g}$ 씩 취하여 $0.85 \%$ 생리식염수 $90 \mathrm{~mL}$ 과 혼합하고 stomacher에서 2분간 균질화 하였다. Glove juice법과 swab 법으로 채취된 시료는 30 초간 vortex한 후 사용하였다. 균질 화 된 시료 $1 \mathrm{~mL}$ 를 취하여 10 배 단계희석한 후 일반세균 및 coliform 측정용 petrifilm ${ }^{\mathrm{TM}}(3 \mathrm{M}, \mathrm{St}$. Paul, $\mathrm{MN}, \mathrm{USA})$ 에 접종하고 $37^{\circ} \mathrm{C} 24$ 시간 배양하였다(18). 또한 E. coli의 측정 은 정량과 정성을 동시에 수행하였다. 정량분석은 $3 \mathrm{M}$ 사의 petrifilm ${ }^{\mathrm{TM}}$ 을 이용하였으며 각 농도별로 $1 \mathrm{~mL}$ 씩 취하여 film에 접종하고 $37^{\circ} \mathrm{C}$ 에서 24 시간 배양 후 기포를 가진 보라 색 집락만을 E. coli로 인정하였다. 최종균수는 전형적인 집락을 보이는 균주×희석배수로 계산하였다. 또한 정성분 석은 고추 및 건고추는 $10 \mathrm{~g}$ 을 취하여 $90 \mathrm{~mL}$ 의 $\mathrm{EC}$ broth(Oxoid, Hampshire, UK)에서 $37^{\circ} \mathrm{C}$ 에서 24시간 증균 배양하였고, glove juice법과 swab법으로 채취한 시료는 1 $\mathrm{mL}$ 를 채취하여 $10 \mathrm{~mL}$ 의 발효관이 든 $\mathrm{EC}$ broth에서 증균하 였다. 배양액 1 loop를 취하여 EMB agar(Oxoid, Hampshire, $\mathrm{UK}$ )에 재접종하였다. 이후 $37^{\circ} \mathrm{C}, 24$ 시간 배양 후 금속광택 을 나타내는 집락을 VITEK(VITEK-2 compact, Biomerieux, l'Etoile, France)으로 최종 동정하였다. 농업용수의 경우 총 대장균군과 대장균 분석을 위하여 농업용수를 원액, 10 배, 
100 배 희석한 후 각 농도 별 $100 \mathrm{~mL}$ 을 취하여 멸균병에 넣은 후 Colilert 18(IDEXX Laboratories, Westbrook, ME, USA)을 첨가하고 혼합하였다. 이후 정량플레이트에 분주 한 후 $37^{\circ} \mathrm{C}, 18-24$ 시간 배양하였다. 총대장균군 판별은 노란 색으로 변한 웰 수를 계수하였고, 대장균은 노란색을 띄고 $365 \mathrm{~nm}$ 에서 형광을 보이는 웰 수를 계수하였다. 이후 MPN 판독표를 이용하여 $100 \mathrm{~mL}$ 속의 균수를 환산하였다.

\section{병원성 미생물 분리 및 동정}

병원성 미생물은 E. coli $\mathrm{O} 157: \mathrm{H} 7$, L. monocytogenes, Salmonella spp.를 정성분석을 하였으며, C. perfringens는 정량분석을 수행하였다. 병원성 미생물 분석은 식품공전법 (17)에 따라 수행하였으며 분석의 특이성을 높이기 위하여 CHROMagar와 PCR법을 병행하였다.

E. coli $\mathrm{O} 157: \mathrm{H} 7$, L. monocytogenes, Salmonella spp.,을 분석하기 위하여 고추와 건고추는 $25 \mathrm{~g}$ 을 취하여 modified EC broth(Oxoid, Hampshire, UK), Listeria enrichment broth (Oxoid), buffered peptone water(Oxoid) $225 \mathrm{~mL}$ 과 혼합하고 stomacher에서 2 분간 균질화 시킨 후 $37^{\circ} \mathrm{C}, 30^{\circ} \mathrm{C}, 37^{\circ} \mathrm{C}$ 에서 24 시간 배양하였다. Glove juice법과 swab법으로 채취된 시료는 30초간 vortex한 후 사용하였다. E. coli $\mathrm{O} 157: \mathrm{H7}$, L. monocytogenes, Salmonella spp.의 분석을 위하여 균질화 된 시료는 $1 \mathrm{~mL}$ 를 채취하여 앞서 언급한 각각의 증균 10 $\mathrm{mL}$ 에 접종하여 $37^{\circ} \mathrm{C}, 30^{\circ} \mathrm{C}, 37^{\circ} \mathrm{C}$ 에서 24 시간 배양하였다. E. coli O157:H7은 증균 배양액을 CHROMagar $\mathrm{O} 157\left(\mathrm{CHROMagar}{ }^{\mathrm{TM}}\right.$, Paris, France)에 접종하여 $37^{\circ} \mathrm{C}$ 에서 24 시간 배양 후 붉은 색을 띄는 colony를 nutrient agar (NA)(Oxoid)에 배양 한 다음 VITEK(VITEK-2 compact, Biomerieux)으로 확인하였다.

L. monocytogenes, Salmonella spp.는 Listeria enrichment broth(Oxoid)와 BPW $225 \mathrm{~mL}$ 에 각각 증균된 배양액을 0.1 $\mathrm{mL}$ 씩 각각 취하여 $10 \mathrm{~mL}$ 의 Fraser broth(Oxoid), Rappaport Vassiliadis R10 Broth(Difco, MD, USA)에 접종하여 각각 $30^{\circ} \mathrm{C}, 42^{\circ} \mathrm{C}$ 에서 24 시간 배양시켰다. 이후 양성의심 시료를 palcam agar(Oxoid), xylose lysine tergitol-4(XLT)(Oxoid)에 접종하여 각각 24 시간 동안 $30^{\circ} \mathrm{C}, 37^{\circ} \mathrm{C}$ 에 배양 후 의심 집락 을 NA에 배양 한 다음 VITEK으로 확인하였다.

C. perfringens는 앞서 위생지표세균측정과 동일한 방법 으로 전처리를 한 후 tryptose sulphite cycloserine agar (TSC)(Oxoid)에 도말하여 $37^{\circ} \mathrm{C}, 24$ 시간 혐기배양하였다. 집 락수를 계수한 후, 희석농도 당 5 개 집락 이상을 NA에 분리 하여 polymerase chain reaction(PCR)로 최종 확인하였다. $\mathrm{PCR}$ 에 사용된 $\mathrm{DNA}$ 추출은 먼저 $300 \mu \mathrm{L}$ 의 멸균 증류수가 든 튜브에 균주 2-3 colony를 현탁하고 $100^{\circ} \mathrm{C}$ 에서 15 분간 처리하였다. 이후 $13,000 \mathrm{rpm}$ 에서 5 분간 원심분리하고 상 등액을 분리하였다. 이를 template DNA로 사용하였다. PCR 은 코젠사의 상용화된 Powercher ${ }^{\mathrm{TM}}$ Clostridium perfringens toxin detection kit(Kogenebiotech, Seoul, Korea)를 이용하였 으며 사용법은 제조사의 매뉴얼에 따라 다음과 같이 진행하 였다. Reaction buffer, taq polymerase, primer가 함유된 $C$. perfringens PCR pre-mix $15 \mu \mathrm{L}$ 와 DNA $5 \mu \mathrm{L}$ 를 혼합하였다. 또한 PCR thermal cycler의 반응 조건은 $95^{\circ} \mathrm{C}$ 에서 10 분간 pre-denaturation을 실시한 후 $94^{\circ} \mathrm{C}$ 에서 30초간 denaturation, $60^{\circ} \mathrm{C}$ 에서 30 초간 primer annealing, $72^{\circ} \mathrm{C}$ 에서 30 초간 extension의 조건으로 $35 \mathrm{cycle}$ 을 수행하고 final extension을 $72^{\circ} \mathrm{C}$ 에서 10 분간 실시하였다. $\mathrm{PCR}$ 에 의한 증폭생성물은 $2.0 \%$ agarose gel 전기영동에 의해 확인하였다.

\section{통계처리}

모든 실험은 3 반복으로 수행되었으며 고추 실험결과의 생산단계별, 고추원료별 차이는 SAS 통계 프로그램 (version 9.1, SAS Institute, NC, USA)의 분산분석(ANOVA procedure)을 이용하여 분석하였다. $\mathrm{p}<0.05$ 수준에서 처리 효과가 유의적인 경우에는 Duncan's Multiple Range test를 이용하여 평균간 다중비교를 하였다(18).

\section{결과 및 고찰}

건고추 생산단계별 일반세균수와 대장균군 오염도 분석

건고추는 비닐하우스 내에서 말리는 자연건조와 건조기 를 이용한 건조 등 크게 두 가지 유형으로 생산된다. 본 연구에서는 노지 재배한 고추와 시설 재배한 고추(비닐하 우스에서 재배)를 세척하고 비닐하우스 혹은 건조기를 이 용하여 건조하는 과정에서 고추의 일반세균수의 변화를 조사하였으며 그 결과는 Fig. 1과 Fig. 2와 같다.

먼저 고추의 재배방식에 따른 건조과정 중 일반세균수의 변화를 비교해 보면 수확직후 노지 재배고추와 시설 재배고 추의 일반세균수 오염수준은 각각 $5.27 \pm 1.32 \log \mathrm{CFU} / \mathrm{g}$, $4.47 \pm 0.70 \log \mathrm{CFU} / \mathrm{g}$ 으로 노지 재배고추의 오염도가 상대 적으로 높았지만 통계적 유의 차이는 없었다 $(\mathrm{p}>0.05)$. 하지 만 세척 후에는 노지 재배고추의 일반세균수가 $6.51 \pm 0.79$ $\log \mathrm{CFU} / \mathrm{g}$, 시설 재배고추의 일반세균수는 $6.96 \pm 0.40 \mathrm{log}$ $\mathrm{CFU} / \mathrm{g}$ 로 비슷한 수준이었고 세척 전에 비하여 각각 1.24 $\log \mathrm{CFU} / \mathrm{g}$ 와 $2.19 \log \mathrm{CFU} / \mathrm{g}$ 가량 증가하였다. 이후 비닐하 우스에서 건조하는 과정 중에 감소하였는데 최종 건조 후 노지 재배고추는 $4.36 \pm 1.00 \log \mathrm{CFU} / \mathrm{g}$ 인 데 반해 시설재배 고추는 $2.82 \pm 0.32 \log \mathrm{CFU} / \mathrm{g}$ 로 유의하게 시설재배고추가 최종 건조되었을 때 노지재배고추를 최종 건조하였을 때보 다 낮았다( $<<0.05)$. 이러한 경향은 건조기를 이용하여 건조 를 하였을 때도 같은 경향이었다.

건조방식에 따른 일반세균수를 비교해 보면 노지 재배한 고추와 시설 재배한 고추를 자연 건조하였을 때 각각 $4.36 \pm 1.00 \log \mathrm{CFU} / \mathrm{g}, 2.82 \pm 0.32 \log \mathrm{CFU} / \mathrm{g}$ 수준인데 반해 
건조기 건조를 하였을 때는 각각 $5.11 \pm 0.81 \log \mathrm{CFU} / \mathrm{g}$, $3.79 \pm 0.70 \log \mathrm{CFU} / \mathrm{g}$ 로 하우스 내에서 자연 건조하는 방식 이 건조기를 이용하여 건조 하는 방식보다 일반세균수가 유의하게 낮았다( $<<0.05)$.

(A)

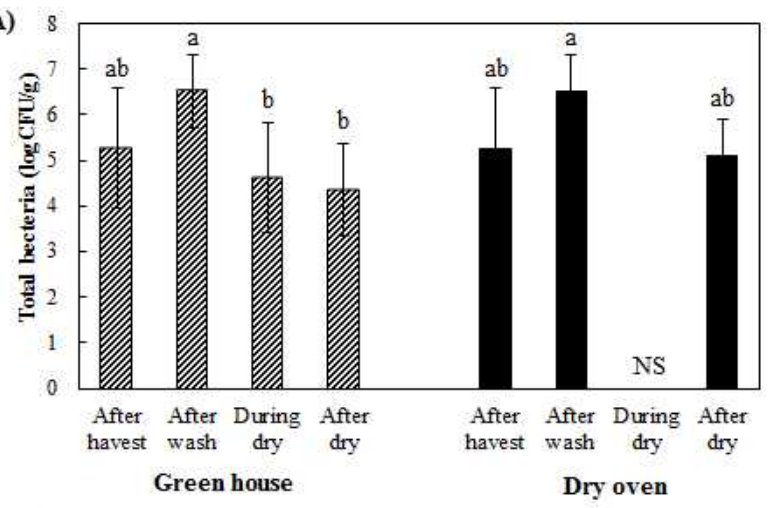

(B)

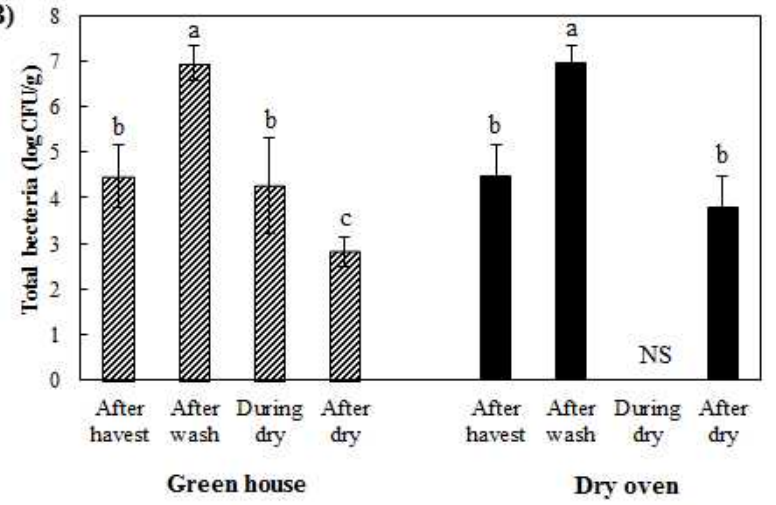

Fig. 1. The mean of total bacteria on red peppers cultivated in field (A) and green house (B) during the drying in green house and dry oven.

The data are present as the mean \pm SD of the nine samples and the same letters are not significantly different among bacterial numbers in each group at $p<0.05$ according to Duncan's test.

NS, not sampled.

또한 대장균군의 경우도 일반세균수의 경향과 같은 경향 을 보였는데 고추의 재배방식에 따른 건조과정 중 대장균군 수의 변화를 비교해 보면 수확 직후 노지 재배고추와 시설 재배고추의 대장균군의 오염수준은 각각 $3.58 \pm 1.57 \mathrm{log}$ $\mathrm{CFU} / \mathrm{g}, 2.91 \pm 1.16 \log \mathrm{CFU} / \mathrm{g}$ 으로 노지 재배고추의 오염도 가 상대적으로 높았다 $(\mathrm{p}<0.05)$. 하지만 세척 후에는 대장균 군이 증가하였으며 노지 재배고추의 대장균군수는 $3.99 \pm$ $0.94 \log \mathrm{CFU} / \mathrm{g}$, 시설 재배고추의 대장균군수는 $>5.0 \mathrm{log}$ $\mathrm{CFU} / \mathrm{g}$ 로 시설 재배고추의 대장균군의 농도가 높았다 (p<0.05). 이후 비닐하우스에서 건조하는 과정 중에 감소하 였는데 최종 건조 후 노지 재배고추는 $1.77 \pm 1.30 \log \mathrm{CFU} / \mathrm{g}$ 인데 반해 시설 재배 고추는 $0.69 \pm 0.88 \log \mathrm{CFU} / \mathrm{g}$ 로 시설 재배고추가 최종 건조되었을 때 노지재배고추를 최종 건조 하였을 때보다 유의하게 낮았다( $\mathrm{p}<0.05)$. 이러한 경향은 건 조기 건조를 하였을 때도 같은 경향이었다. 건조방식에 따
른 대장균군수를 비교해 보면 노지 재배한 고추와 시설 재배한 고추를 비닐하우스 내에서 건조하였을 때 각각 $1.77 \pm 1.30 \log \mathrm{CFU} / \mathrm{g}, 0.69 \pm 0.88 \log \mathrm{CFU} / \mathrm{g}$ 수준인데 반해 건조기 건조를 하였을 때는 각각 $3.09 \pm 0.68 \log \mathrm{CFU} / \mathrm{g}$, $2.35 \pm 0.77 \log \mathrm{CFU} / \mathrm{g}$ 로 하우스 내에서 건조하는 방식이 건조기 건조를 하는 방식보다 대장균군수가 유의하게 낮았 다(p<0.05). 이는 두 건조 방식의 온도와 건조 기간의 차이 에 의한 것으로 판단된다. 총 10 일 정도 소요되는 비닐하우 스 내에서 건조하는 방식은 3 일 차까지는 하우스 상단에 차광망을 씨우고 하우스 문을 열고 건조하다가 4일 차에는 맛과 색을 좋게 하기 위하여 차광망을 걷고 하우스의 문을 닫고 1 일 동안 고추를 건조한다. 이 때 최고온도가 $75^{\circ} \mathrm{C}$ 정도 로 높게 상승하게 된다. 이후 하우스 문을 개방하고 6일 더 건조하여 건고추를 생산한다. 건조기에서 건조하는 방 식은 $55-60^{\circ} \mathrm{C}$ 내외로 3 일 정도 건조하는데 비닐하우스에서 건조할 때보다 온도도 낮고 건조기간도 짧아서 미생물의 생장 억제정도가 상대적으로 낮을 것으로 판단된다.

$\mathrm{Nam}$ 등(19)의 연구에 따르면 수확한 고추에서 일반세균

(A)

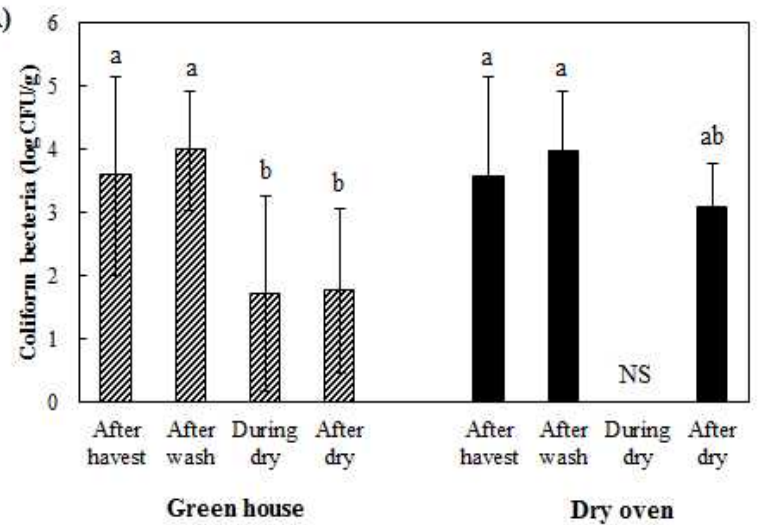

(B)

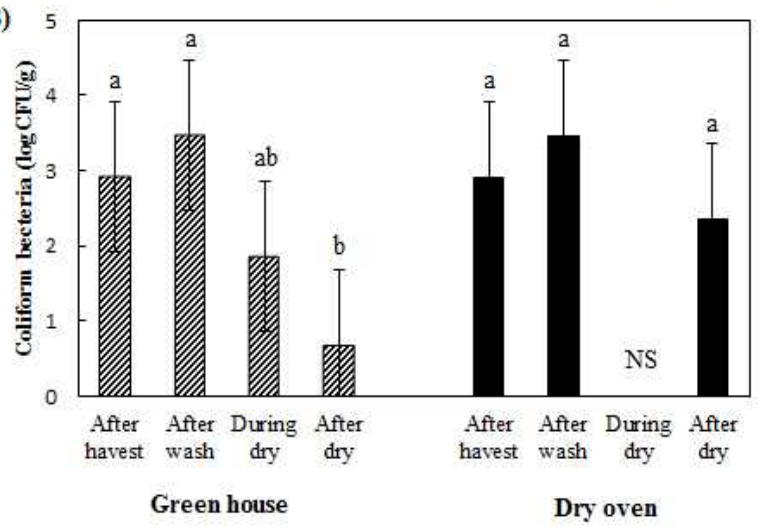

Fig. 2. The mean of coliform bacteria on red peppers cultivated in field (A) and greenhouse (B) during the drying in green house naturally and dry oven.

The data are present as the mean $\mathrm{SD}$ of the nine samples and the same letters are not significantly different among bacterial numbers in each group at $p<0.05$ according to Duncan's test. NS, not sampled. 
이 약 $4.5 \log \mathrm{CFU} / \mathrm{pepper}$ 수준으로 검출되었으며, Woo 등(20)의 연구에서는 약 $3.37 \log \mathrm{CFU} / \mathrm{g}$ 으로 검출되었다고 보고하였다. 본 연구에서는 다른 연구 결과보다 약 $1.0 \mathrm{log}$ $\mathrm{CFU} / \mathrm{g}$ 이상 더 높게 오염 되어 있었다. 또한 건조가 완료된 건고추에서의 다른 연구결과를 보면, Byun 등(21)의 연구 에서 건조 통고추에서 약 $3.1 \log \mathrm{CFU} / \mathrm{g}$ 이 검출되었다고 보고하고 있으며, Kim 등(22)의 연구에서도 약 $2.2 \mathrm{log}$ $\mathrm{CFU} / \mathrm{g}$ 수준으로 보고하고 있다. 본 연구와 유사하게 건조 전 고추보다 건고추에서 일반세균수가 낮은 수준으로 검출 되었는데 이는 건조로 인하여 사멸된 것으로 판단된다. 한 편 노지재배와 시설재배에 의해 수확된 고추의 일반세균수 와 대장균군수의 차이가 있었는데 이는 노지재배는 야생동 물의 출입, 폭우나 폭풍 등의 미생물 오염원에 노출되어 있는데 반해 시설 재배의 경우 자연 재해 및 야생동물의 출입을 차단할 수 있기 때문에 노지 재배에 비하여 미생물 의 오염이 비교적 낮다고 사료된다(23-25). 하지만 재배방 식에 관계없이 세척하면서 고추 중의 일반세균수와 대장균 군의 수가 증가하였는데 이는 미생물에 오염된 고추를 세척 기 내에서 물 세척하는 과정 중에 교차오염에 의해 발생하 는 것으로 판단된다. 따라서 건조에 앞서 세척과정에 미생 물 저감화 기술을 투입한다면 건조 후에 최종 건고추의 일반세균수, 대장균군의 오염도를 낮추는데 기여할 것으로 생각된다.

건고추 생산단계별 대장균 및 병원성 미생물 오염도 분석 건고추 생산 단계별 대장균을 조사 결과, $\mathrm{A}$ 농가 시설에 서 재배하고 세척한 고추에서 대장균이 검출되었으나 나머 지 두 농가에서는 수확, 세척, 건조가 완료되기까지의 전단 계에서 검출되지 않았다(data not shown).

Listeria spp.의 경우 B 농가 시설 재배 고추에서 Listeria seeligeri 혹은 $L$ welshiment으로 추정되는 균이 검출되었다 (Table 1). 이는 세척용수의 오염 때문으로 판단되는데 $\mathrm{A}$ 농가의 세척수에서는 대장균이, $\mathrm{B}$ 농가의 세척수에서는 Listeria spp.가 검출되어 있어 오염된 세척 수에 의해 고추 가 오염되는 것으로 추정된다(Table 2). 한편 세척 이후 고추 를 건조하는 과정에서 사멸하여 최종 생산된 건고추에서는 대장균 및 Listreia spp.는 검출되지 않았다.
식중독세균은 $64^{\circ} \mathrm{C}$ 에서 10 분 이상 가열하면 대부분 사멸 한다고 알려져 있지만 대장균을 비롯한 일부 식중독세균은 $71^{\circ} \mathrm{C}$ 이상에도 사멸하지 않는 메커니즘을 갖는 경우가 알려 져 있다(26). 내열성을 갖는 대장균은 열충격이 왔을 때 세포벽을 유지하고 잘못 접힌 단백질을 회전하는 역할을 하는 단백질을 encode하는 $16 \mathrm{ORFs}$ (open reading frames)을 포함하는 $14 \mathrm{~kb}$ 의 유전자 island를 가지고 있기 때문이라 보고되고 있다(27). 따라서 건조 전에 대장균을 비롯한 병원 성미생물을 완벽하게 제거하지 못하면 건조하는 과정에서 살아남아 이후 건고추나 고춧가루의 안전성에 영향을 끼칠 수 있기 때문에 세척수의 안전성을 확보하고 세척과정에 병원성미생물이 오염되는 것을 예방하는 것이 필요하다고 사료된다.

건고추 생산환경 및 장갑의 위생지표세균 및 병원성 미생 물 오염도 분석

건고추 생산환경의 미생물 오염도를 조사하기 위하여 세척수, 세척기, 수확용기, 건조실, 건조기, 작업자 장갑에 대하여 위생지표세균과 병원성미생물 오염도를 조사하고 그 결과는 다음과 같다(Table 2-4).

세척수는 세척하는 과정에 농산물과 직접 접촉하기 때문 에 농산물의 미생물 안전에 영향을 미친다. 세척기로 유입 되기 전 지하수의 오염도를 조사한 결과 Table 2에서 보는 바와 같이 대장균군은 $0.75 \pm 0.68 \log \mathrm{MPN} / 100 \mathrm{~mL}$ 이었고 $\mathrm{A}$ 농가에서 대장균이 검출되었으며 $\mathrm{B}$ 농가에서는 Listeria spp.가 검출되었다. 국내 농산물을 세척하는데 사용하는 물의 경우 먹는물 수질 기준에 적합한 기준의 물을 사용하 도록 권장하고 있다(28). 먹는물 수질 기준은 일반세균수 $2.0 \log \mathrm{CFU} / \mathrm{mL}$ 이하, 대장균군과 대장균, 그 외 병원성미 생물이 검출되지 않아야 한다(29). 하지만 본 연구에 사용된 세척수는 이 기준을 충족하지 못하고 있기 때문에 세척수 기기에 유입되기 전에 지하수를 소독할 수 있는 장치 설치 와 주기적인 수질 검사가 필요하다고 사료된다.

건고추 생산에 이용되는 세척기의 경우 고추가 들어가는 입구, 세척 중인 세척기 내부, 세척 후 나오는 출구를 조사하 였다. 일반세균수는 평균적으로 약 $1.33 \pm 1.26 \log \mathrm{CFU} / \mathrm{cm}^{2}$ 이 검출되었으며, 대장균군의 경우 $0.69 \pm 0.94 \log \mathrm{CFU} / \mathrm{cm}^{2}$

Table 1. Detection rate of Listeria spp. from red peppers cultivated in field and greenhouse during the drying in green house and dry oven

\begin{tabular}{|c|c|c|c|c|c|c|c|c|c|}
\hline & & \multicolumn{4}{|c|}{ Red pepper cultivated in fields } & \multicolumn{4}{|c|}{ Red pepper cultivated in greenhouse } \\
\hline & & $\mathrm{A}$ & B & $\mathrm{C}$ & Total & $\mathrm{A}$ & $\mathrm{B}$ & $\mathrm{C}$ & Total \\
\hline \multicolumn{2}{|c|}{ Harvested } & $0 / 3(0 \%)$ & $0 / 3(0 \%)$ & $0 / 3(0 \%)$ & $0 / 9(0 \%)$ & $0 / 3(0 \%)$ & $2 / 3(66.6 \%)$ & $0 / 3(0 \%)$ & $2 / 9(22.2 \%)$ \\
\hline \multicolumn{2}{|c|}{ After wash } & $0 / 3(0 \%)$ & $0 / 3(0 \%)$ & $0 / 3(0 \%)$ & $0 / 9(0 \%)$ & $0 / 3(33.3 \%)$ & $1 / 3(33.3 \%)$ & $0 / 3(0 \%)$ & $1 / 9(11.1 \%)$ \\
\hline \multirow{2}{*}{ Drying in green house } & During dry & $0 / 3(0 \%)$ & $0 / 3(0 \%)$ & $0 / 3(0 \%)$ & $0 / 9(0 \%)$ & $0 / 3(0 \%)$ & $0 / 3(0 \%)$ & $0 / 3(0 \%)$ & $0 / 9(0 \%)$ \\
\hline & After dry & $0 / 3(0 \%)$ & $0 / 3(0 \%)$ & $0 / 3(0 \%)$ & $0 / 9(0 \%)$ & $0 / 3(0 \%)$ & $0 / 3(0 \%)$ & $0 / 3(0 \%)$ & $0 / 9(0 \%)$ \\
\hline Drying in dry oven & After dry & $0 / 3(0 \%)$ & $0 / 3(0 \%)$ & $0 / 3(0 \%)$ & $0 / 9(0 \%)$ & $0 / 3(0 \%)$ & $0 / 3(0 \%)$ & $0 / 3(0 \%)$ & $0 / 9(0 \%)$ \\
\hline
\end{tabular}


Table 2. The level of indicator bacteria and the detection rate of Listeria spp. in water used for washing red peppers

\begin{tabular}{ccccccccccc}
\hline \multirow{2}{*}{ Samples } & \multicolumn{4}{c}{ Coliform } & \multicolumn{4}{c}{ E. coli } & \multicolumn{3}{c}{ Listeria spp. } \\
\cline { 2 - 11 } & $\mathrm{A}$ & $\mathrm{B}$ & $\mathrm{C}$ & Average & $\mathrm{A}$ & $\mathrm{B}$ & $\mathrm{C}$ & $\mathrm{A}$ & $\mathrm{B}$ & $\mathrm{C}$ \\
\hline Ground water & $1.54 \pm 0.23^{\mathrm{a} 1)}$ & $0.71 \pm 0.09^{\mathrm{b}}$ & $0.0 \pm 0.0^{\mathrm{c}}$ & $0.75 \pm 0.68$ & $0.46 \pm 0.15^{\mathrm{a}}$ & $0.0 \pm 0.0^{\mathrm{b}}$ & $0.0 \pm 0.0^{\mathrm{b}}$ & $0 / 3(0 \%)$ & $3 / 3(100 \%)$ & $0 / 3(0 \%)$ \\
Water for washing & $0.77 \pm 0.39^{\mathrm{c}}$ & $3.00 \pm 0.0^{\mathrm{a}}$ & $1.58 \pm 0.14^{\mathrm{b}}$ & $1.78 \pm 1.00$ & $0.0 \pm 0.0^{\mathrm{a}}$ & $0.0 \pm 0.0^{\mathrm{a}}$ & $0.0 \pm 0.0^{\mathrm{a}}$ & $2 / 3(67 \%)$ & $0 / 3(0 \%)$ & $0 / 3(0 \%)$ \\
Water for rinsing & $0.34 \pm 0.36^{\mathrm{b}}$ & $0.70 \pm 0.45^{\mathrm{b}}$ & $1.47 \pm 0.22^{\mathrm{a}}$ & $0.84 \pm 0.59$ & $0.0 \pm 0.0^{\mathrm{a}}$ & $0.0 \pm 0.0^{\mathrm{a}}$ & $0.0 \pm 0.0^{\mathrm{a}}$ & $0 / 3(0 \%)$ & $0 / 3(0 \%)$ & $0 / 3(0 \%)$ \\
Water after rinsing & $2.97 \pm 0.01^{\mathrm{a}}$ & $\mathrm{NS}^{2)}$ & $2.96 \pm 0.07^{\mathrm{a}}$ & $2.97 \pm 0.05$ & $3.00 \pm 0.0^{\mathrm{a}}$ & $\mathrm{NS}$ & $0.81 \pm 1.41^{\mathrm{b}}$ & $0 / 3(0 \%)$ & $\mathrm{NS}$ & $0 / 3(0 \%)$ \\
\hline
\end{tabular}

${ }^{1}$ The same letter is not significantly different among the coliform bacterial number of 3 farms at $p<0.05$ according to Duncan's test.

${ }^{2} \mathrm{NS}$, not sampled.

Table 3. The level of indicator bacteria from equipment and glove used for washing and drying red peppers

\begin{tabular}{|c|c|c|c|c|c|c|c|c|c|}
\hline \multirow{2}{*}{ Process } & \multirow{2}{*}{ Samples } & \multicolumn{4}{|c|}{ Total bacteria } & \multicolumn{4}{|c|}{ Coliform } \\
\hline & & A & B & $\mathrm{C}$ & Average & A & B & $\mathrm{C}$ & Average \\
\hline \multirow{5}{*}{ Washing } & $\begin{array}{l}\text { Washing machine } \\
\text { (raw pepper input area) }\end{array}$ & $1.27 \pm 1.25^{\mathrm{a} 1)}$ & $2.20 \pm 0.61^{\mathrm{a}}$ & $2.80 \pm 1.04^{\mathrm{a}}$ & $2.09 \pm 1.10$ & $0.10 \pm 0.17^{\mathrm{a}}$ & $1.03 \pm 0.93^{\mathrm{a}}$ & $1.37 \pm 1.72^{\mathrm{a}}$ & $0.83 \pm 1.13$ \\
\hline & $\begin{array}{l}\text { Washing machine } \\
\text { (washing area) }\end{array}$ & $2.97 \pm 0.64^{\mathrm{a}}$ & $0.73 \pm 1.27^{b}$ & $0.33 \pm 0.58^{b}$ & $1.34 \pm 1.45$ & $2.00 \pm 0.53^{\mathrm{a}}$ & $0.90 \pm 0.85^{\mathrm{ab}}$ & $0.00 \pm 0.00^{b}$ & $0.97 \pm 1.45$ \\
\hline & $\begin{array}{l}\text { Washing machine } \\
\text { (rinsing area) }\end{array}$ & $1.17 \pm 0.67^{\mathrm{a}}$ & $0.50 \pm 0.87^{\mathrm{a}}$ & $0.00 \pm 0.00^{\mathrm{a}}$ & $0.56 \pm 0.75$ & $0.33 \pm 0.58^{\mathrm{a}}$ & $0.43 \pm 0.75^{\mathrm{a}}$ & $0.00 \pm 0.00^{\mathrm{a}}$ & $0.26 \pm 0.51$ \\
\hline & $\begin{array}{c}\text { Container } \\
\text { (for collection of washed pepper) }\end{array}$ & $1.27 \pm 0.61^{\mathrm{a}}$ & $3.13 \pm 0.59^{\mathrm{a}}$ & $2.03 \pm 1.79^{\mathrm{a}}$ & $2.14 \pm 1.28$ & $0.00 \pm 0.00^{\mathrm{b}}$ & $1.80 \pm 0.26^{\mathrm{a}}$ & $0.87 \pm 1.50^{\mathrm{ab}}$ & $0.89 \pm 1.09$ \\
\hline & Glove & $7.73 \pm 1.15^{\mathrm{a}}$ & $4.03 \pm 2.63^{\mathrm{a}}$ & $6.60 \pm 0.57^{\mathrm{a}}$ & $6.06 \pm 2.33$ & $>5.00^{\mathrm{a}}$ & $0.63 \pm 1.10^{c}$ & $4.85 \pm 0.35^{\mathrm{b}}$ & $4.60 \pm 2.29$ \\
\hline $\begin{array}{l}\text { Drying in } \\
\text { green house }\end{array}$ & Floor in green house & $0.00 \pm 0.00^{\mathrm{b}}$ & $3.17 \pm 0.32^{\mathrm{a}}$ & $2.87 \pm 0.87^{\mathrm{a}}$ & $2.02 \pm 1.34$ & $0.00 \pm 0.00^{\mathrm{a}}$ & $0.00 \pm 0.00^{\mathrm{a}}$ & $0.00 \pm 0.00^{\mathrm{a}}$ & $0.00 \pm 0.00$ \\
\hline $\begin{array}{l}\text { Drying in dry } \\
\text { oven }\end{array}$ & Tray in dry oven & $2.00 \pm 0.44^{\mathrm{a}}$ & $3.33 \pm 1.01^{\mathrm{a}}$ & $2.37 \pm 1.18^{\mathrm{a}}$ & $2.57 \pm 1.00$ & $0.00 \pm 0.00^{\mathrm{a}}$ & $0.00 \pm 0.00^{\mathrm{a}}$ & $0.00 \pm 0.00^{\mathrm{a}}$ & $0.00 \pm 0.00$ \\
\hline
\end{tabular}

${ }^{11}$ The same letter is not significantly different among the coliform bacterial number of 3 farms at $p<0.05$ according to Duncan's test.

Table 4. Detection rate of $E$. coli and Listeria spp. from equipment and glove used for washing and drying red peppers

\begin{tabular}{|c|c|c|c|c|c|c|c|c|c|}
\hline \multirow{2}{*}{ Process } & \multirow{2}{*}{ Samples } & \multicolumn{4}{|c|}{ E. coli } & \multicolumn{4}{|c|}{ Listeria spp. } \\
\hline & & $\mathrm{A}$ & B & $\mathrm{C}$ & Total & $\mathrm{A}$ & $\mathrm{B}$ & $\mathrm{C}$ & Total \\
\hline \multirow{5}{*}{ Washing } & $\begin{array}{l}\text { Washing machine } \\
\text { (raw pepper input area) }\end{array}$ & $\begin{array}{l}0 / 3 \\
(0 \%)\end{array}$ & $\begin{array}{c}0 / 3 \\
(0 \%)\end{array}$ & $\begin{array}{l}0 / 3 \\
(0 \%)\end{array}$ & $0 / 9(0 \%)$ & $\begin{array}{l}0 / 3 \\
(0 \%)\end{array}$ & $\begin{array}{l}0 / 3 \\
(0 \%)\end{array}$ & $\begin{array}{l}0 / 3 \\
(0 \%)\end{array}$ & $\begin{array}{l}0 / 9 \\
(0 \%)\end{array}$ \\
\hline & $\begin{array}{l}\text { Washing machine } \\
\text { (washing area) }\end{array}$ & $\begin{array}{c}1 / 3 \\
(33.3 \%)\end{array}$ & $\begin{array}{c}0 / 3 \\
(0 \%)\end{array}$ & $\begin{array}{l}0 / 3 \\
(0 \%)\end{array}$ & $\begin{array}{c}1 / 9 \\
(11.1 \%)\end{array}$ & $\begin{array}{c}1 / 3 \\
(33.3 \%)\end{array}$ & $\begin{array}{l}0 / 3 \\
(0 \%)\end{array}$ & $\begin{array}{l}0 / 3 \\
(0 \%)\end{array}$ & $\begin{array}{c}1 / 9 \\
(11.1 \%)\end{array}$ \\
\hline & $\begin{array}{l}\text { Washing machine } \\
\text { (rinsing area) }\end{array}$ & $\begin{array}{c}0 / 3 \\
(0 \%)\end{array}$ & $\begin{array}{c}0 / 3 \\
(0 \%)\end{array}$ & $\begin{array}{c}0 / 3 \\
(0 \%)\end{array}$ & $\begin{array}{l}0 / 9 \\
(0 \%)\end{array}$ & $\begin{array}{c}0 / 3 \\
(0 \%)\end{array}$ & $\begin{array}{l}0 / 3 \\
(0 \%)\end{array}$ & $\begin{array}{l}0 / 3 \\
(0 \%)\end{array}$ & $\begin{array}{l}0 / 9 \\
(0 \%)\end{array}$ \\
\hline & $\begin{array}{c}\text { Container } \\
\text { (for collection of washed pepper) }\end{array}$ & $\begin{array}{l}0 / 3 \\
(0 \%)\end{array}$ & $\begin{array}{c}0 / 3 \\
(0 \%)\end{array}$ & $\begin{array}{l}0 / 3 \\
(0 \%)\end{array}$ & $\begin{array}{l}0 / 9 \\
(0 \%)\end{array}$ & $\begin{array}{l}0 / 3 \\
(0 \%)\end{array}$ & $\begin{array}{c}0 / 3 \\
(0 \%)\end{array}$ & $\begin{array}{l}0 / 3 \\
(0 \%)\end{array}$ & $\begin{array}{l}0 / 9 \\
(0 \%)\end{array}$ \\
\hline & Glove & $\begin{array}{c}1 / 3 \\
(33.3 \%)\end{array}$ & $\begin{array}{c}0 / 3 \\
(0 \%)\end{array}$ & $\begin{array}{c}1 / 3 \\
(33.3 \%)\end{array}$ & $\begin{array}{l}2 / 9 \\
(22.2 \%)\end{array}$ & $\begin{array}{c}0 / 3 \\
(0 \%)\end{array}$ & $\begin{array}{c}0 / 3 \\
(0 \%)\end{array}$ & $\begin{array}{l}0 / 3 \\
(0 \%)\end{array}$ & $\begin{array}{l}0 / 9 \\
(0 \%)\end{array}$ \\
\hline $\begin{array}{l}\text { Drying in green } \\
\text { house }\end{array}$ & Floor in green house & $\begin{array}{c}0 / 3 \\
(0 \%)\end{array}$ & $\begin{array}{c}0 / 3 \\
(0 \%)\end{array}$ & $\begin{array}{c}0 / 3 \\
(0 \%)\end{array}$ & $\begin{array}{c}0 / 9 \\
(0 \%)\end{array}$ & $\begin{array}{c}0 / 3 \\
(0 \%)\end{array}$ & $\begin{array}{c}0 / 3 \\
(0 \%)\end{array}$ & $\begin{array}{l}0 / 3 \\
(0 \%)\end{array}$ & $\begin{array}{l}0 / 9 \\
(0 \%)\end{array}$ \\
\hline Drying in dry oven & Tray in dry oven & $\begin{array}{l}0 / 3 \\
(0 \%)\end{array}$ & $\begin{array}{c}0 / 3 \\
(0 \%)\end{array}$ & $\begin{array}{c}0 / 3 \\
(0 \%)\end{array}$ & $\begin{array}{c}0 / 9 \\
(0 \%)\end{array}$ & $\begin{array}{c}0 / 3 \\
(0 \%)\end{array}$ & $\begin{array}{c}0 / 3 \\
(0 \%)\end{array}$ & $\begin{array}{c}0 / 3 \\
(0 \%)\end{array}$ & $\begin{array}{c}0 / 9 \\
(0 \%)\end{array}$ \\
\hline
\end{tabular}

이 검출되었다. 또한 $\mathrm{A}$ 농가의 세척기 내부에서 대장균과 Listeria spp.가 검출되어 세척하는 과정에서 고추로 교차오 염원이 될 가능성이 높다고 판단된다. 앞서 고추의 대장균
오염도 결과에서도 고추를 세척하는 과정에 미생물 오염도 가 증가하였고 $\mathrm{A}$ 농가에서 세척후의 고추에서 대장균이 검출된 사례로 볼 때 세척과정의 세척수의 안전성과 세척기 
내부의 청결, 원료 고추에 대장균이 오염되어왔을 경우를 대비하여 세척과정 중의 농가 맞춤형 제어 기술이 종합적으 로 투입되어야 할 것으로 판단된다.

세척 후 고추를 수거하는 용기의 경우 일반세균은 $2.14 \pm 1.28 \log \mathrm{CFU} / \mathrm{cm}^{2}$, 대장균군의 경우 $0.89 \pm 1.09 \mathrm{log}$ $\mathrm{CFU} / \mathrm{cm}^{2}$ 로 세척기와 유사한 수준으로 검출되었다. 작업자 장갑의 경우 일반세균은 $6.06 \pm 2.33 \log \mathrm{CFU} / \mathrm{hand}$, 대장균군 의 경우 $4.60 \pm 2.29 \log \mathrm{CFU} / \mathrm{hand}$ 이 검출되었고 두 농가의 장갑에서 대장균도 검출되었다. 한편 E. coli $\mathrm{O} 157: \mathrm{H7}$, Salmonella spp., L. monocytogenes, C. perfringens는 모든 샘플에서 검출되지 않았다(data not shown). 작업자의 손이 나 장갑의 미생물 오염도가 타 시료에 비해 높다는 사실은 다른 연구자들의 연구결과에서도 지속적으로 보고되고 있 을 뿐만 아니라(30-31) 고추의 수확, 세척 작업은 대부분 수작업으로 이루어지고 있기 때문에 미생물에 오염된 장갑 에 의해 고추로 교차 오염의 가능성이 있다. 영국 Campden $\mathrm{BRI}$ 연구소에서는 미생물에 오염된 장갑을 통하여 샐러드, 파스타, 햄 등으로 미생물이 전이되는 것을 증명하였고(32), Verhaelen 등(33)은 노로바이러스와 아데노바이스의 surrogate를 장갑에 접종하고 장갑에 의해 상추로 바이러스 의 전이율을 조사 한 결과, 각각 $25 \%, 18 \%$ 가 전이된다고 보고하여 미생물이나 바이러스에 오염된 장갑은 농산물로 충분히 전이될 수 있음을 확인할 수 있다. 따라서 장갑의 주기적인 교체와 세척이 필요하다고 사료된다.

이상의 결과를 종합해 볼 때 고춧가루의 안전성 확보를 위해서는 건고추를 안전하게 생산하는 것부터 시작되어야 한다고 사료된다. 특히 고추를 생산하고 세척하는 단계에 안전관리는 건고추 안전에 직접적인 영향을 미칠 수 있다고 판단되며 이를 위해서는 현장에 맞는 세척법 개발과 농업인 에 대한 지속적인 위생교육이 필요할 것으로 사료된다.

\section{요 약}

본 연구는 건고추와 건고추 생산환경의 미생물 오염도를 조사하고자 수행하였다. 이를 위하여 고추 농장에서 수확 후, 세척 후, 건조 후 고추, 세척용수, 세척기, 수확용기, 작업자 장갑, 건조기 등의 시료를 채취하여 위생지표세균 (일반세균수, 대장균군, E. coli)과 병원성미생물(Escherichia coli O157:H7, Salmonella spp., Listeria monocytogenes, Clostridium perfringens)을 조사하였다. 그 결과, 수확 된 고추를 세척 한 이후에 일반세균수와 대장균군의 수가 유의 적으로 증가하였고 $(\mathrm{p}<0.05)$ 세척 후의 고추에서 대장균 및 Listeria spp.가 검출되었다. 이들 세균이 검출된 농가의 물 에서도 각각 대장균과 Listeria spp.가 검출되어 세척수에 오염으로 추정된다. 또한 건조 방식에 따라 일반세균수와 대장균수의 유의적인 차이가 있었는데 비닐하우스에서 건
조한 고추의 일반세균수와 대장균군의 수가 건조기에서 건조한 고추보다 유의적으로 낮았다 $(\mathrm{p}<0.05)$. 하지만 $E$. coli O157:H7, Salmonella spp., L. monocytogenes, $C$. perfringens는 모든 시료에서 검출되지 않았다. 따라서 본 연구의 결과로 미루어 볼 때 건고추의 안전성 확보를 위해 서는 세척수의 안전관리와 세척단계에 고추 중에 존재하는 미생물을 제어하는 기술이 개발되어야 할 것으로 사료된 다. 아울러 건조기를 이용하여 건고추를 생산할 경우 온도 설정 등 미생물 제어에 적절한 방식이 개발되어야 할 것으 로 생각된다.

\section{감사의 글}

본 연구는 농촌진흥청 국립농업과학원 농업과학기술 연 구개발사업(과제번호: PJ012676)의 지원에 의해 이루어진 것임

\section{References}

1. Cho SI, Bae YM, Noh DH (1997) Measurement of moisture and fat contents in pepper-powder using near-infrared spectroscopy. Food Eng Prog, 1, 133-136

2. Kwon JH, Lee GD, Byun MW, Choi KJ, Kim HK (1998) Changes in water activity and fatty acid composition of dried red pepper during post irradiation period. Korean J Food Sci Technol, 30, 1058-1063

3. MFDS (2016) Food code. Ministry of Food and Drug Safety. Cheongju, Korea, 148-149

4. Jeong MS, Ahn JJ, Akram K, Kim GR, Im JG, Kwon JH (2013) Microbiological and physicochemical quality characterization of commercial red pepper powders. J Food Hyg Saf, 28, 1-6

5. Song YJ, Park SW, Chun SC, Choi MJ, Chung KC, Lee SK (2012) Efficient treatment methods for reducing Escherichia coli populations in commercially available red pepper powder in Korea. J Korean Soc Food Sci Nutr, 41, 875-880

6. Rico CW, Kim GR, Ahn JJ, Kim HK, Furuta M, Kwon $\mathrm{JH}$ (2010) The comparative effect of steaming and irradiation on the physicochemical and microbiological properties of dried red pepper (Capsicum annum L.). Food Chem, 119, 1012-1016

7. Almela L, Nieto-Sandoval JM, Fernandez JA (2002) Microbial inactivation of paprika by a high- temperature short-X time treatment. Influence on color properties. J 
Agric Food Chem, 50, 1435-1440

8. Sahraie P, Mostaghim T, Rahman A (2016) Steammicrowave on reduction of microbial level of red pepper and compared with gamma irradiation. IJSRST, 2, 49-57

9. Byun MW, Kwon JH, Lee JW, Cho HO (1986) Evaluation of sensory quality of spices treated with ethylene oxide and ionizing radiation. Korean J Food Sci Technol, 18, 417-430

10. Yun H, Park K, Ryu KY, Kim SR, Yun JC, Kim BS (2012) Effects of LED treatment on microbial reduction and quality characteristics of red pepper powder. J Food Hyg Saf, 27, 442-448

11. Schweiggert U, Carle R, Schieber A (2007) Conventional and alternative processes for spice production - a review. Trends Food Sci Technol, 18, 260-268

12. Fowles J, Mitchell J, McGrath H (2001) Assessment of cancer risk from ethylene oxide residues in spices imported into New Zealand. Food Chem Toxicol, 39, 1055-1062

13. Fine F, Gervais P (2004) Efficiency of pulsed UV light for microbial decontamination of food powders. J Food Prot, 67, 787-792

14. Song HP, Kim B, Choe JH, Jung S, Moon SY, Choe W, Jo C (2009) Evaluation of atmospheric pressure plasma to improve the safety of sliced cheese and ham inoculated by 3-strain cocktail Listeria monocytogenes. Food Microbiol, 26, 432-436

15. Farkas J (1998) Irradiation as a method for decontaminating food: a review. Int J Food Microbiol, 44, 189-204

16. US Food and Drug Administration (1978) Guidelines for effectiveness testing of surgical hand scrub (glove juice test). Federal Register, 43, 1242-1243

17. Ministry of food and drug safety : Korean Food code. http://fse.foodnara.go.kr/ (accessed October 2012)

18. Carmer SG, Walker WM (1985) Pairwise multiple comparisons of treatment means in agronomic research. J Agron Educ, 14, 19-26

19. Nam MJ, Heo RW, Lee WG, Kim KY, Chung DY, Kim JS, Shim WB, Chung DH (2011) Microbiological hazard analysis of hot pepper farms for the application of good agricultural practices (GAP) system. J Agric Life Sci, 45, 163-173

20. Woo HI, Kim JB, Choi JH, Kim EH, Kim DS, Park KS, Kim EJ, Eun JB, OM AS (2012) Evaluation of the level of microbial contamination in the manufacturing and processing company of red pepper powder. J Food Hyg Saf, 27, 427-431
21. Byun MW, Yook HS, Kwon JH, Kim JO (1996) Improvement of hygienic quality and long-term storage of dried red pepper by gamma irradiation. Korean J Food Sci Technol, 28, 482-489

22. Kim BK, Kausar T, Kim DH, Kwon JH (2005) Effects of gamma-irradiation and fumigation on microbial growth, color and absorption properties of dried red pepper during storage. Korean J Food Preserv, 12, 48-53

23. Holvoet K, Sampers I, Seynnaeve M, Jacxsens L, Uyttendaele M (2015) Agricultural and management practices and bacterial contamination in greenhouse versus open field lettuce production. Int J Environ Res Public Health, 12, 32-63

24. Kirezieva K, Nanyunja J, Jacxsens L, Vorst JG, Uyttendaele M, Luning PA (2013) Context factors affecting design and operation of food safety management systems in the fresh produce chain. Trends Food Sci Technol, 32, 108-127

25. Parker JK, McIntyre D, Noble RT (2010) Characterizing fecal contamination in stormwater runoff in coastal North Carolina, USA. Water Res, 44, 4186-4194

26. Ma A, Chui L (2017) Identification of heat resistant Escherichia coli by qPCR for the locus of heat resistance. J Microbiol Methods, 133, 87-89

27. Mercer RG, Zheng J, Garcia-Hernandez R, Ruan L, Ganzle MG, McMullen LM (2015) Genetic determinants of heat resistance in Escherichia coli. Front Microbiol, 6, 1-13

28. Kim HW, Cho JR, Cho SM, Ha JH, Kim GC, Kim SR, Kim WI, Ryu SH, Choi JH (2015) Explanation of standards for good agricultural practices (GAP). Rural Development Administration, Jeonju, Korea, 34-36

29. Ministry of Environment (2017) Explanation of standards for drinkable water. Ministry of Environment, Sejong, Korea, 180-188

30. Kim SR, Lee JY, Lee SH, Ko HS, Yoon YH, Kwon SH, Ryu KY, Yun HJ, Kim WI, Yun JC, Kim DH, Chung DH (2011) Distribution of microorganisms in perilla leaf cultivation area. Korean J Food Sci Technol, 43, 243-248

31. Park SH, Kim JS, Kim KY, Chung DH, Sim WB (2013) Identification of toxin gene and antibiotic resistance of Staphylococcus aureus isolated from agricultural product cultivation environments. J Environ Health Sci, 39, 465-473

32. Todd ECD, Michaels BS, Greig JD, Smith D, Bartleson CA (2010) Outbreaks where food workers have been implicated in the spread of foodborne disease. part 8 . 
gloves as barriers to prevent contamination of food by workers. J Food Prot, 73, 1762-1773

33. Verhaelen K, Bouwknegt M, Carratala A, LodderVerschoor F, Diez-Valcarce M, Rodriguez-Lazaro D,
Husman AMR, Saskia Rutjes A (2013) Virus transfer proportions between gloved fingertips, soft berries, and lettuce, and associated health risks. Int J Food Microbiol, $166,419-425$ 